\title{
Real-life outcomes of unselected acute promyelocytic leukemia patients: a single-center 14-year experience
}

\author{
OMER FARUK AKCAY ${ }^{1}$, HACI HASAN YETER ${ }^{1}$, YAHYA BUYUKASIK ${ }^{2}$ \\ ${ }^{1}$ Gazi University Faculty of Medicine, Department of Nephrology, Ankara, Turkey \\ ${ }^{2}$ Hacettepe University Faculty of Medicine, Department of Hematology, Ankara, Turkey
}

\begin{abstract}
Background. After the inclusion of all-trans retinoic acid (ATRA) into the treatment of Acute Promyelocytic leukemia (APL), a notable improvement concerning the survival rates of patients with APL has been observed. However, the population-based studies demonstrated that there was no marked improvement in the survival of patients after the 2000s. We aim to describe the clinical response and prognosis of adult patients diagnosed with APL and examine the change in these outcomes by the time period of diagnosis.

Methods. We retrospectively reviewed thirty-six unselected APL patients who were diagnosed between September 2003 and February 2016.

Results. The probability of survival at two years was $58 \%$, while disease-free survival (DFS) was $87 \%$. The overall early death (ED) rate was $33 \%$ and remain stable over time [ $42 \%$ in $2003-2009$ vs. $24 \%$ in $2010-2016(\mathrm{p}=.20)$ ]. In addition, the 2 -year overall survival (OS) rates were $47 \%$ in $2003-$ 2009 and $70 \%$ in $2010-2016(p=.29)$, and no differences were noted. Univariate analyses showed possible predictors of poor OS were defined as leukocytosis $\left(\geq 10 \times 10^{9} / \mathrm{L}\right)$, high Sanz score, hemorrhage, infection, disseminated intravascular coagulopathy (DIC) at presentation and microgranular morphologic subtype.

Conclusions. This study shows that long-term survival remains low in APL patients, particularly related to a high ED rate. Initiatives to reduce ED are exceedingly substantial for improving the survival in APL.
\end{abstract}

Key words: acute promyelocytic leukemia, early death, overall survival, real-life outcomes, predictors.

\section{INTRODUCTION}

Acute promyelocytic leukemia (APL) is a subtype of acute myeloid leukemia, which is characterized by distinct morphologic and cytogenetic aberrations and a potentially life-threatening coagulopathy. APL is defined as balanced reciprocal translocation $t(15 ; 17)$ which is present in more than $98 \%$ of cases, resulting in the fusion of PML (promyelocytic leukemia) and RAR $\alpha$ (retinoic acid receptor- $\alpha$ ) genes that lead to the production of the oncoprotein PML-RAR $\alpha$ [1]. Patients mostly present with peripheral cytopenias, including low or normal total white blood cell count (WBC).

APL is a rare disease $(600-800$ cases/year in the USA) that accounts for approximately $5 \%$ of all AML patients [2]. The frequency of APL seems to be higher in some countries of Latin America and some European populations [3, 4]. For many years, APL had a poor prognosis with a rate of early death (ED) due to hemorrhages from disseminated intravascular coagulation (DIC), hypercoagulability, fibrinolysis, proteolysis and thrombocytopenia, infections and multi-organ failure. In the 1970s, anthracycline-based therapies produced complete remission in $65-80 \%$ and long-term survival in $15-30 \%$ of patients with APL $[5,6]$. After the addition of all-trans retinoic acid (ATRA) to induction therapy, notable improvement has been seen in the survival of APL [7].

Large, multicenter clinical trials have reported the rate of ED between 5 and $10 \%[8,9]$. 5-year disease-free survival (DFS) and overall survival (OS) rates above $80 \%$. However, many patients (up to $30 \%$ ) excluded from these trials because of high age, poor performance status (PS), abnormal hepatic or kidney function, or other comorbidities; therefore, trials may underestimate the actual mortality rates associated with APL $[10,11]$. Also, some trials have excluded patients from analyses if they die before receiving treatment [6]. On the other hand, in population-based analyses and single-center experiences from different countries, the rate of induction mortality rate is up to $61.5 \%$, which is higher than expected [11-14]. Especially populationbased reports from the developed countries emphasize 
neither ED nor OS improved in the past two decades despite modern therapy methods [15-17]. Nevertheless, APL remains associated with a high incidence of ED.

This study intended to investigate the clinical response and prognosis of newly diagnosed APL patients in our real-life experience. We also sought to examine the change in these data with the time of diagnosis.

\section{MATERIALS AND METHODS}

\section{Study population}

This retrospective study conducted at Hacettepe University Hospital. The Ethics Committee approved the design and procedures of the study (Protocol ID: 567) in agreement with the principles of the Declaration of Helsinki and ethical standards for human experimentation. Written informed consent was taken from all participants. Thirty-six cases of newly diagnosed APL treated at Hacettepe University Hospital from September 2003 to February 2016 were included in this study.

\section{Diagnosis}

APL diagnosis established based on WHO criteria and was carried out by evaluation of hemogram, peripheral blood smear, marrow aspirate with immune phenotyping, cytogenetics, and reversetranscriptase polymerase chain reaction (RT-PCR) for promyelocytic leukemia/retinoic acid receptor alpha (PML/RAR $\alpha)$ [1]. Leukemic cells were analyzed by flow cytometry, and the diagnosis was validated by the presence of $t(15 ; 17)$ with fluorescence in situ hybridization (FISH) analysis.

\section{Treatment}

Induction therapy consisted of oral ATRA (45 $\mathrm{mg} / \mathrm{m}^{2} /$ day) divided into two daily doses plus idarubicin $\left(12 \mathrm{mg} / \mathrm{m}^{2} /\right.$ day) given as an intravenous bolus on days 2, 4, 6 and 8 (AIDA regimen). Treatment with ATRA was started as soon as a diagnosis of APL was made by morphologic criteria and maintained until complete hematologic remission or for a maximum of 90 days. Consolidation and maintenance treatment was also given according to the AIDA regimen [18].

Supportive therapy was applied to patients during the diagnosis and treatment period. Treatment with platelets, fresh frozen plasma, or cryoprecipitate transfusion was administered when bleeding occurred. Patients received fresh frozen plasma in case of any $\mathrm{PT} / \mathrm{aPTT} / \mathrm{TT}$ derangement and to keep fibrinogen $>100 \mathrm{mg} / \mathrm{dL}$. Prophylactic platelet transfusion strategy was available when the platelet count was less than $50 \times 10^{9} / \mathrm{L}$. Packed red cell transfusions were recommended to maintain blood hemoglobin greater than $8 \mathrm{~g} / \mathrm{dL}$. Prophylaxis for differentiation syndrome (DS) was not given. At the first signs of suspected DS, patients were given $10 \mathrm{mg}$ dexamethasone every 12 hours. ATRA was interrupted only in case of progression to severe DS.

\section{Study outcomes}

All clinical and follow-up data were collected retrospectively by reviewing the charts of patients. Risk stratification at presentation based on the Sanz score was performed [19]. Performance status was measured according to the Eastern Cooperative Oncology Group (ECOG)/World Health Organization (WHO) scale and grouped as $(0-1, \geq 2)$.

Complete remission (CR) was defined as less than $5 \%$ of abnormal promyelocytes in bone marrow aspirate, along with neutrophil count $>1 \times 10^{9} / \mathrm{L}$, platelet count $>100 \times 10^{9} / \mathrm{L}$ in peripheral blood. ED was defined as death occurring during induction therapy. OS was defined as the time from the day of registration until death, last follow-up or censoring of the data on the patients. DFS was defined as the time from CR to relapse, death from any cause, last follow-up, or censoring of the data on the patients. We examined the data on patients treated at our institution during approximately the same time period that were predetermined according to the year of diagnosis: 2003-2009 and 2010-2016.

\section{Statistical analysis}

Data obtained in the study were analyzed statistically using Statistical Package for the Social Science software version 25 (IBM Corpn., SPSS for Windows. Armonk, NY, USA). Data distribution was determined using the Kolmogorov-Smirnov test. The homogeneity of variables was determined using the One-way ANOVA homogeneity of variance test. Symmetrically distributed variables in the text and tables were shown as mean \pm standard deviation values. If the distribution was heterogeneous, variables were shown as median (min-max) values. Categorical variables were stated as number (n) and percentage (\%). The Student's t-test or the Mann-Whitney U test were used to compare continuous variables, 
and the Chi-square test or Fisher's exact test was used to compare categorical variables according to the data distribution. Cox regression analysis was used to identify possible predictors of overall survival in patients with APL. Overall and disease free survival was assessed by Kaplan-Meier analysis, and the difference was evaluated by log-rank tests. $P$ value $\leq 0.05$ was considered to indicate statistical significance.

\section{RESULTS}

\section{Patients}

We identified 36 patients who underwent initial treatment at our center from September 2003 to February 2016. The median age was 39 years (18-78), with a female predominance $(56 \%)$. The median presenting leukocyte count of the patients was $2 \times 10^{9} / \mathrm{L}(0.5-200)$. Using the Sanz risk criteria, there were $11(31 \%), 14(38 \%)$, and $11(31 \%)$ patients with high, intermediate, and low-risk disease, respectively. Nine $(25 \%)$ patients applied to our clinic with any bleeding, 24 (66\%) patients had an infection, and 16 (44\%) patients had DIC during the disease presentation. When we separated the patients into two groups according to the time of diagnosis (2003-2009 vs. 2010-2016), we found a significant difference only in gender distribution [14 $(74 \%)$ vs. $6(35 \%)$ for female, $p=.02]$. Other features of the patients were similar between both time periods. The clinical characteristics of the total cohort are summarized in Table 1.

Table 1

Demographic characteristics of patients

\begin{tabular}{|c|c|c|c|c|}
\hline & \multirow{2}{*}{\multicolumn{2}{|c|}{ Time period of diagnosis }} & \multirow[b]{3}{*}{$P$ value } \\
\hline & & & & \\
\hline Variable & $\begin{array}{l}\text { Total patients } \\
\quad \mathrm{n}=36\end{array}$ & $\begin{array}{c}2003-2009 \\
n=19\end{array}$ & $\begin{array}{c}2010-2016 \\
n=17\end{array}$ & \\
\hline \multicolumn{5}{|c|}{ Gender } \\
\hline $\begin{array}{l}\text { Male }(\mathrm{n}, \%) \\
\text { Female (n,\%) }\end{array}$ & $\begin{array}{l}16(44) \\
20(56)\end{array}$ & $\begin{array}{c}5(26) \\
14(74)\end{array}$ & $\begin{array}{l}11(65) \\
6(35)\end{array}$ & 0.02 \\
\hline $\begin{array}{c}\text { Age (years) } \\
\text { Median (range) }\end{array}$ & $62(18-97)$ & $37(17-79)$ & $41(19-63)$ & $0.21^{\mathrm{a}}$ \\
\hline \multicolumn{5}{|c|}{ Peripheral blood counts, median (range) } \\
\hline Hemoglobin $(\mathrm{g} / \mathrm{dl})$ & $9.15(4.0-15.6)$ & $9.1(6.1-14.0)$ & $9.3(4.0-15.6)$ & $0.76^{\mathrm{a}}$ \\
\hline White blood cells $\left(\times 10^{9} / \mathrm{L}\right)$ & $2(0.5-200)$ & $2.6(0.6-200)$ & $1.8(0.5-150)$ & $0.50^{\mathrm{a}}$ \\
\hline Platelets $\left(\times 10^{9} / \mathrm{L}\right)$ & $20(5-231)$ & $19(10-231)$ & $28(5-153)$ & $0.68^{\mathrm{a}}$ \\
\hline \multicolumn{5}{|c|}{ Symptom at presentation (n,\%) } \\
\hline Hemorrhage & $9(25)$ & $4(21)$ & $5(29)$ & 0.70 \\
\hline DIC & $16(44)$ & $9(47)$ & $7(41)$ & 0.97 \\
\hline Infection & $24(66)$ & $12(63)$ & $12(70)$ & 0.63 \\
\hline \multicolumn{5}{|c|}{ ECOG PS (n,\%) } \\
\hline $\begin{array}{l}0-1 \\
\geq 2\end{array}$ & $\begin{array}{l}26(72) \\
10(28)\end{array}$ & $\begin{array}{l}12(63) \\
7(37)\end{array}$ & $\begin{array}{l}14(82) \\
3(18)\end{array}$ & 0.27 \\
\hline \multicolumn{5}{|c|}{ Sanz risk group $(\mathrm{n}, \%)$} \\
\hline $\begin{array}{l}\text { Low } \\
\text { Intermediate } \\
\text { High } \\
\end{array}$ & $\begin{array}{l}11(31) \\
14(38) \\
11(31) \\
\end{array}$ & $\begin{array}{l}5(26) \\
7(37) \\
7(37) \\
\end{array}$ & $\begin{array}{l}6(35) \\
7(41) \\
4(24) \\
\end{array}$ & 0.67 \\
\hline \multicolumn{5}{|c|}{ Morphologic classification (n, \%) } \\
\hline $\begin{array}{l}\text { Classic } \\
\text { Microgranular variant }\end{array}$ & $\begin{array}{l}28(78) \\
8(22)\end{array}$ & $\begin{array}{c}13(68) \\
6(32)\end{array}$ & $\begin{array}{l}15(88) \\
2(12)\end{array}$ & 0.23 \\
\hline
\end{tabular}

${ }^{a}$ Mann-Whitney U test

\section{Early death and treatment response}

The overall ED rate was 33\% (12/36) during the study period, with a median time to death was 12 days (1-26). Bleeding was the main cause of death at this period [intracranial (7/12) and abdominal hemorrhages (1/12)]. Infection (3/11) was the second common reason for death in this period. DS was diagnosed in 11 patients $(31 \%)$, one of whom died due to DS during the induction therapy. Comparison of ED rates in 2003-2009 and in 2010-2016 were similar $(42 \%$ vs. $24 \%, \mathrm{p}=.20)($ Table 2$)$. 
Table 2

Treatment results of APL patients by the time period of diagnosis

\begin{tabular}{|c|c|c|c|c|}
\hline Variable & Total & 2003-2009 & 2010-2016 & $P$ value \\
\hline Number of patients (n) & 36 & 19 & 17 & \\
\hline \multicolumn{5}{|l|}{ Induction results $(\mathrm{n}, \%)$} \\
\hline Early death & $12(33)$ & $8(42)$ & $4(24)$ & 0.20 \\
\hline Complete hematological remission & $24(67)$ & $11(58)$ & $13(76)$ & \\
\hline Differentiation syndrome in induction & $11(31)$ & $8(42)$ & $3(18)$ & 0.11 \\
\hline \multicolumn{5}{|c|}{ Outcome at 2 years $(\%[95 \% \mathrm{CI}])$} \\
\hline Overall survival & $58 \pm 8$ & $47 \pm 11$ & $70 \pm 11$ & $0.29^{\mathrm{a}}$ \\
\hline Disease free survival & $87 \pm 7$ & $82 \pm 11$ & $92 \pm 7$ & $0.94^{\mathrm{a}}$ \\
\hline
\end{tabular}

${ }^{a}$ Log-rank test.

Twenty-four patients (67\%) achieved complete hematologic remission after induction (median 32 days, range 18-90 days) and proceeded to consolidation therapy. There were three deaths $(8 \%)$ occurred in the consolidation phase. Two patients died because of sepsis and the other by central nervous system bleeding. At the end of the consolidation therapy, 21 patients achieved molecular remission.

\section{Long-term outcome}

The median follow-up of the entire cohort was $11.4(0.07-126.8)$ months. The 2-year OS and DFS of all 36 patients were $58 \%$ and $87 \%$, respectively (Figure 1A-B). Survival decreased markedly in the first three months after the diagnosis. The 2-year OS rates were $47 \% \pm 11 \%$ in patients diagnosed between $2003-2009$ and $70 \% \pm 11 \%$ in patients diagnosed between 2010-2016 $(\mathrm{p}=.29$; Table 2).

A

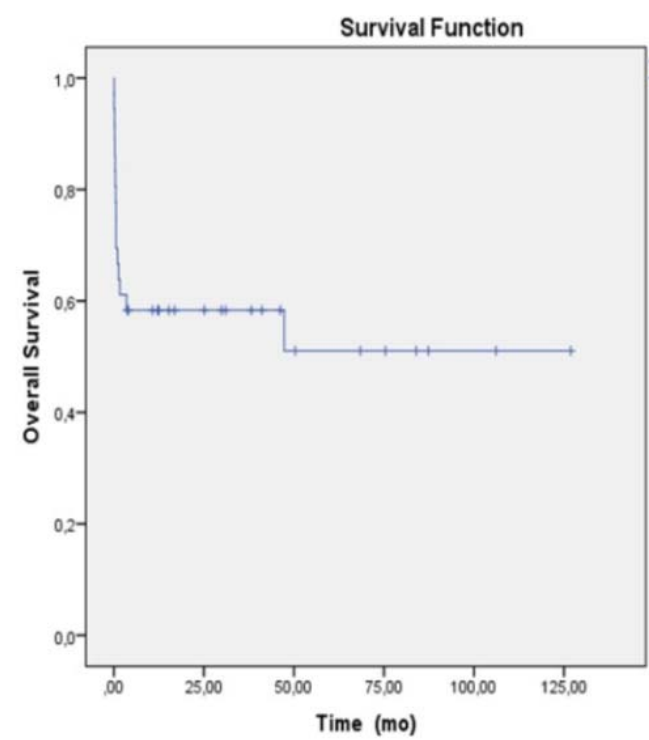

After induction treatment median follow-up of the surviving patients was 29.3 months. The 2-year DFS rates were $82 \% \pm 11 \%$ in $2003-2009$ and $92 \% \pm 7 \%$ in 2010-2016 ( $\mathrm{p}=.94$; Table 2). Kaplan-Meier curves of OS and DFS by both time periods are shown in Figure 2A-B.

Possible predictors of poor OS were defined as leukocytosis [hazard ratio (HR) : 6.33 (95\% confidence interval (CI) (2.19-18.31), $\mathrm{p}=.001$ ], high Sanz score [HR : $6.3795 \% \mathrm{Cl}(1.66-24.32), \mathrm{p}=.007]$, DIC [HR : $4.3295 \% \mathrm{Cl}(1.46-12.76), \mathrm{p}=.008$ ], hemorrhage [HR : $3.2995 \% \mathrm{Cl}(1.16-9.35), \mathrm{p}=.02]$, infection at diagnosis [HR : $5.0595 \% \mathrm{Cl}(1.11-22.31), \mathrm{p}=.03$ ], ECOG PS $\geq 2$ [HR : $3.7195 \% \mathrm{Cl}(2.12-6.50), \mathrm{p}<.001]$ and microgranular morphologic subtype [HR : 4.81 $95 \% \mathrm{Cl}(1.74-13.27), \mathrm{p}=.002]$ on cox proportional hazard regression analysis. No differences were observed by gender, age, thrombocytopenia and the time period of diagnosis (Table 3 ).

B

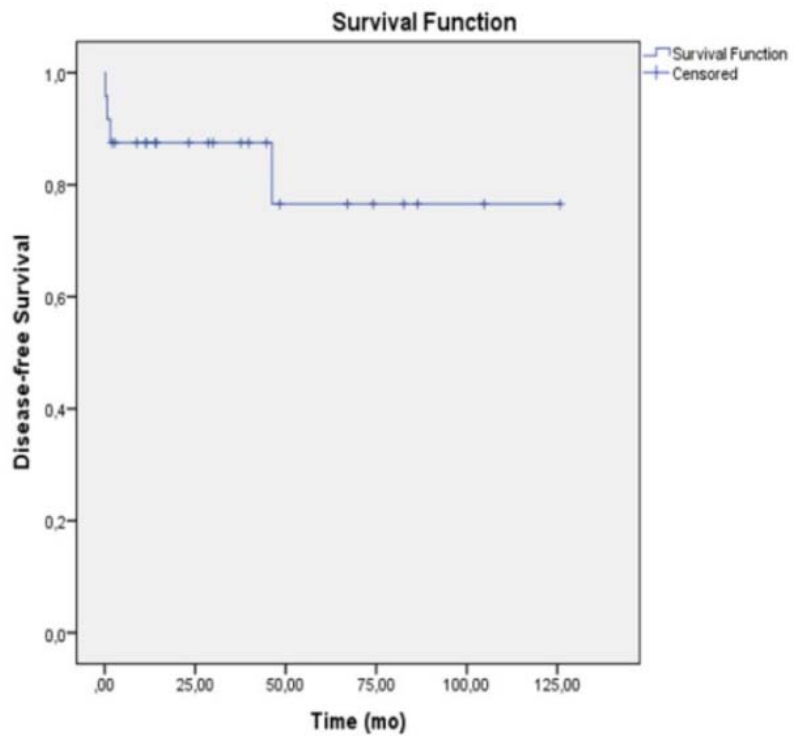

Figure 1A-B. Two-year overall and disease free survival of all patients. 
A

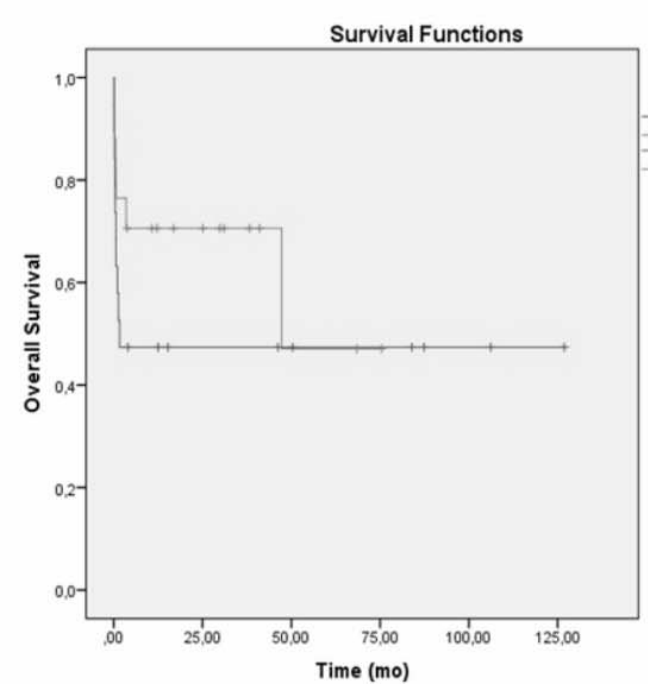

B

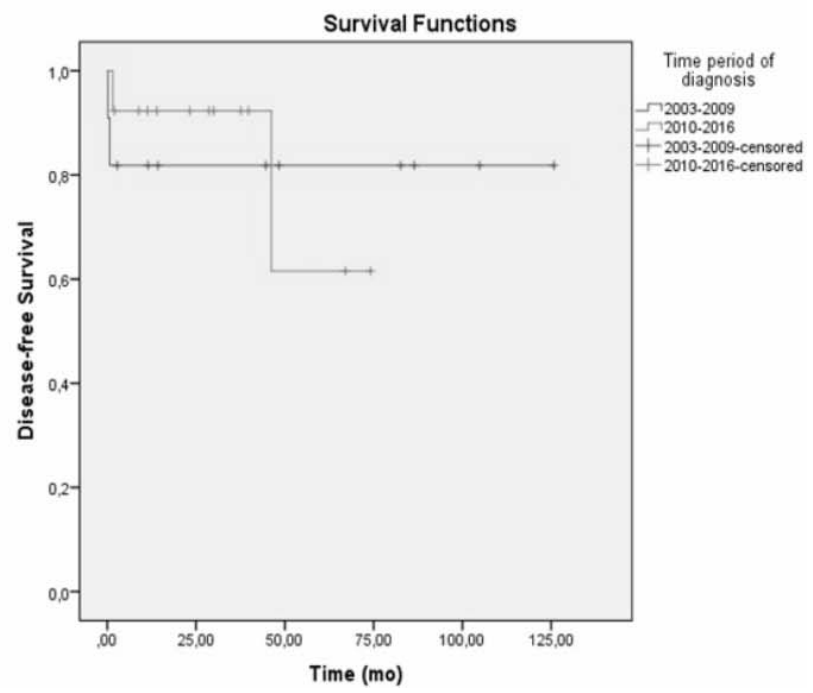

Figure 2A-B. Two-year overall and disease free survival by the time of diagnosis.

Table 3

Cox proportional hazards regression analysis for risk factors to predict overall survival in patients with APL

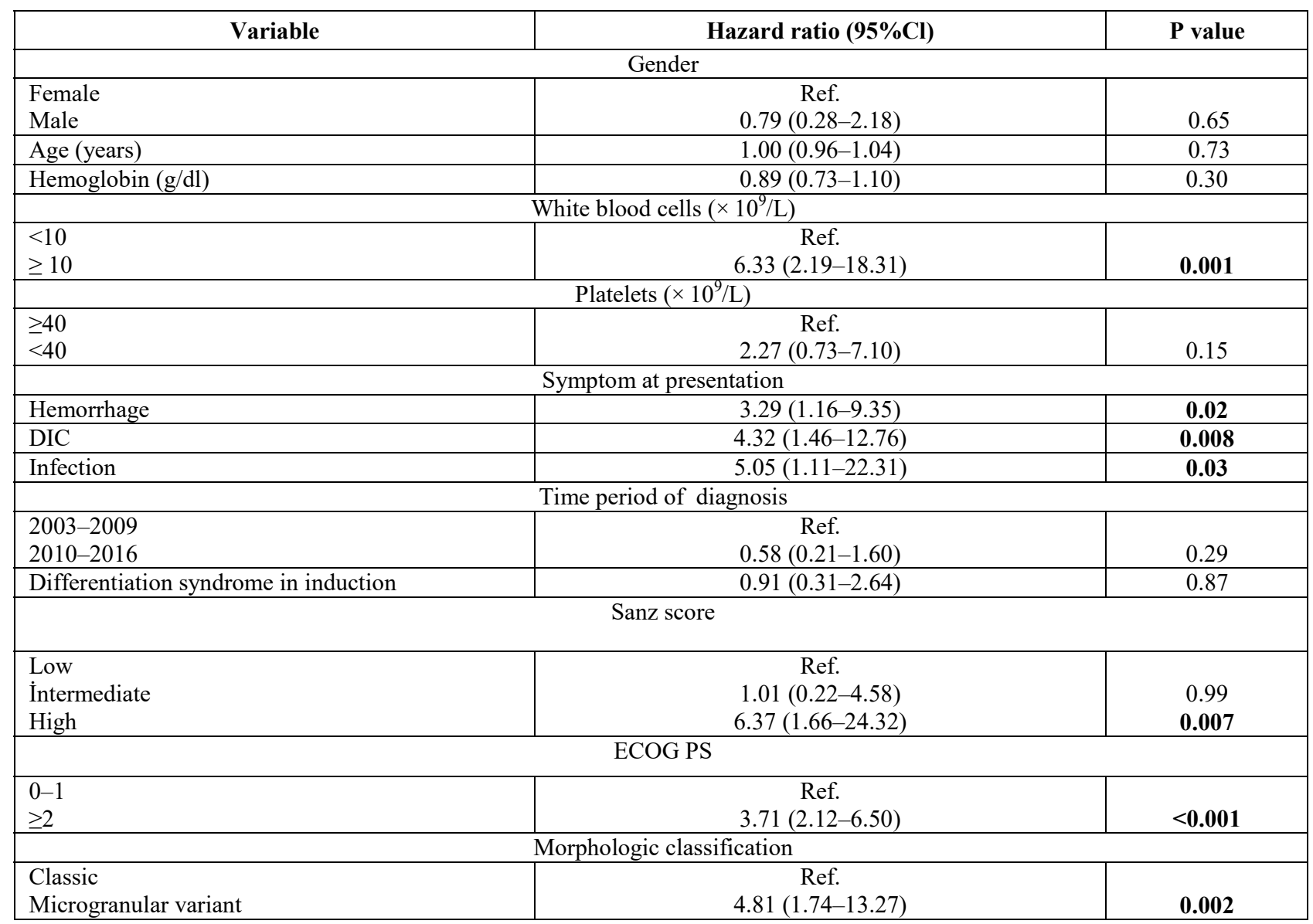

During the follow-up period, no relapse was observed. Only one patient died due to secondary malignancy. The patient died because of MDS/AML in the $48^{\text {th }}$ month of follow-up.

\section{DISCUSSION}

In this single-center retrospective study, we present our results of ED, survival rates and 
change of these parameters over time in patients with APL. We demonstrated that ED remains a major problem and causes shortening of overall survival in these patients. However, we demonstrated that there were no favorable changes regarding ED, OS, and DFS during the 14 years. Also, we found that the presentation form of the disease, high Sanz and ECOG scores, and microgranular morphologic subtype were associated with poor prognosis.

Significant improvements have been achieved since the addition of ATRA to APL therapy from the early 1990s. Multicenter clinical trials with newly diagnosed APL patients reported high response rates and ATRA approved by the FDA for the treatment of APL [20]. Subsequently, ATRA plus chemotherapy with idarubicin (or daunorubicin) and/or cytarabine became the standard induction regimen for APL $[21,22]$. In many randomized clinical trials, the ED rate was reported as $5 \%$ to $10 \%[9,22,23]$. Nevertheless, many population-based studies demonstrated higher ED rates of $20-32 \%$ [11, 24, $25]$. We found that the overall ED rate in our study was $33 \%$, and it was similar to population-based studies. The most frequent cause of ED in our study was hemorrhage and infection. In this study, the distribution of the causes of death during the induction therapy was similar to previous reports [26, 27]. The main reason for the higher ED rates contrasted with trials is probably the inclusion of patients with very early deaths, and also patients with poor performance status, higher Sanz risk score, and lifethreating coagulopathy/hemorrhage at diagnosis [28]. Compared to 7-year time periods (2002-2009 and 2010-2016) to examine change over time, there was no significant improvement in ED, which was still represented the most important reason for treatment failure [24, 29].

The 2-year OS was $58 \%$, and it was lower than the expected range for adult APL. Disappointingly, this rate was very similar to historical data [30], OS was lower than the randomized clinical trials $[31,32]$. Noteworthy, patients with high risk according to the Sanz score, ECOG PS $\geq 2$ (31\%), and infection at presentation $(66 \%)$ were constituted an essential part of our study, which is higher than in the majority of other APL studies [10,32]. This may have caused a lower OS rate in our study. We defined leukocytosis, higher Sanz score, DIC, hemorrhage, infection at diagnosis, poor performance status, and microgranular morphologic subtype as risk factors for reduced OS. In many studies, the relationship between these factors and OS has been demonstrated $[24,33]$. However, age was not a risk factor for OS in our study. Similar to our result, the Danish Registry was reported that while the age is not an independent risk factor for OS, the performance status of the patients is the main determinant of OS [34]. This may reflect the importance of performance status rather than the age during the treatment process.

In the present study, we observed no improvement in 2-year OS rates from 2003-2009 to 2010-2016. Similarly, epidemiologic data demonstrated that there was no significant change in survival and remained relatively stable in recent years $[16,34]$. However, The International Consortium on Acute Promyelocytic Leukemia (IC-APL) demonstrated that the effort to recognize and treat APL early had been associated with significantly improved 2-year OS up to $80 \%$ in developing countries [35]. Another remarkable finding of our study was 2-year DFS of patients was $87 \%$. It pointed at the expected survival rate of patients who achieved complete remission is high. Considering these findings, that was critical to evaluate patients with clinical suspicion of APL immediately to reduce early death and increase longterm survival.

The study has several limitations. The first and major important limitation is that this study was single center. Within the limits of single-center and rare nature of the disease, the study population was localized and included a small number of patients. These were limiting the analytic possibilities. Second, the design of the study is not sufficient to establish a cause and effect relationship.

In conclusion, our study showed that longterm survival remains low in APL patients, particularly related to a high ED rate. Improvement of the prognosis in APL patients seems dependent on increased clinical awareness, rapid confirmation of the diagnosis, and prompt initiation of ATRA treatment. Improving early death rates should be the main objective for the future treatment of APL.

Introducere. Odată cu introducerea tratamentului cu acid transretinoic (ATRA) pentru tratamentul leucemiei acute promielocitare (APL) s-a observat o creştere a supraviețuirii acestor pacienţi. Totuşi studiile populaţionale nu au putut observa o îmbunătăţire majoră a supraviețirii pacienţilor după anii 2000. Scopul studiului a fost de a descrie răspunsul clinic şi prognosticul pacienţilor adulţi care s-au prezentat cu diagnosticul APL. 
Metode. Au fost analizate retrospectiv 36 de cazuri cu APL diagnosticate intre septembrie 2013 şi februarie 2016.

Rezultate. Supravieţuirea la 2 ani de la diagnostic a fost de 58\%. Iar supravietuirea disease free (DFS) a fost de $87 \%$. Rata mortalitătii a fost de $33 \%$ şi a rămas stabilă pe parcursul celor 14 ani (42\% in 2003-2009 vs. 24\% in 2010-2016 ( $p=0,20)$. In plus supravieţuirea la 2 ani a fost 47\% în 2003-2009 şi 70\% în 2010-2016 ( $p=0,29)$. Analiza univariată a arătat că leucocitoza (mai mare de $10 \times 10^{9} / \mathrm{L}$ ), scorul mare Sanz, hemoragia, infecţia, sindromul de coagulare intravasculară diseminată şi subtipul morfologic microgranular au avut prognostic mai prost.

Concluzii. Studiul a arătat ca supravieţuirea a rămas redusă la pacienţii cu APL.

Correspondence to: Omer Faruk AKCAY, M.D, Gazi University, Department of Nephrology, ANKARA, TURKEY, Zipcode: 06560 E-mail: omerfaruk_akcay@yahoo.com Tel: +905546992867

Conflict of interest disclosure: The authors declare that they have no conflict of interest.

\section{REFERENCES}

1. DE BRAEKELEER E., DOUET-GUILBERT N., and DE BRAEKELEER M., RARA fusion genes in acute promyelocytic leukemia: a review. Expert Rev Hematol, 2014. 7(3): p. 347-357.

2. GIRI S., PATHAK R., ARYAL M.R., KARMACHARYA P., and BHATT V.R., Second primary malignancy in acute promyelocytic leukemia: a Surveillance, Epidemiology and End Results database study. Future Oncol, 2017. 13(17): p. 1455-1457.

3. THULER L.C.S. and POMBO-DE-OLIVEIRA M.S., Acute promyelocytic leukaemia is highly frequent among acute myeloid leukaemias in Brazil: a hospital-based cancer registry study from 2001 to 2012. Ann Hematol, 2017. 96(3): p. 355-362.

4. DINMOHAMED A.G. and VISSER O., Incidence of acute promyelocytic leukemia across Europe: results of RARECAREnet-a population-based study. Stem Cell Investig, 2019. 6: p. 37-37.

5. KANTARJIAN H.M., KEATING M.J., WALTERS R.S., ESTEY E.H., MCCREDIE K.B., SMITH T.L., et al., Acute promyelocytic leukemia. M.D. Anderson Hospital experience. Am J Med, 1986. 80(5): p. 789-97.

6. TALLMAN M.S., ANDERSEN J.W., SCHIFFER C.A., APPELBAUM F.R., FEUSNER J.H., OGDEN A., et al., All-transretinoic acid in acute promyelocytic leukemia. N Engl J Med, 1997. 337(15): p. 1021-8.

7. FENAUX P., CASTAIGNE S., DOMBRET H., ARCHIMBAUD E., DUARTE M., MOREL P., et al., All-transretinoic acid followed by intensive chemotherapy gives a high complete remission rate and may prolong remissions in newly diagnosed acute promyelocytic leukemia: a pilot study on 26 cases. Blood, 1992. 80(9): p. 2176-81.

8. LO-COCO F., AVVISATI G., VIGNETTI M., THIEDE C., ORLANDO S.M., IACOBELli S., et al., Retinoic Acid and Arsenic Trioxide for Acute Promyelocytic Leukemia. N Engl J Med, 2013. 369(2): p. 111-121.

9. SANZ M.A., MONTESINOS P., RAYÓN C., HOLOWIECKA A., DE LA SERNA J., MILONE G., et al., Risk-adapted treatment of acute promyelocytic leukemia based on all-trans retinoic acid and anthracycline with addition of cytarabine in consolidation therapy for high-risk patients: further improvements in treatment outcome. Blood, 2010. 115(25): p. 5137-5146.

10. MICOL J.B., RAFFOUX E., BOISSEL N., LENGLINE E., CANET E., DANIEL M.T., et al., Management and treatment results in patients with acute promyelocytic leukaemia (APL) not enrolled in clinical trials. Eur J Cancer, 2014. 50(6): p. 1159-68.

11. LEHMANN S., RAVN A., CARLSSON L., ANTUNOVIC P., DENEBERG S., MÖLLGÅRD L., et al., Continuing high early death rate in acute promyelocytic leukemia: a population-based report from the Swedish Adult Acute Leukemia Registry. Leukemia, 2011. 25(7): p. 1128-1134.

12. PAGONI M., GAROFALAKI M., PANITSAS F., MANOLA K., PSARRA K., ECONOMOPOULOS P., et al., Acute promyelocytic leukemia: an experience on 95 greek patients treated in the all-trans-retinoic Acid era. Mediterr J Hematol Infect Dis, 2011. 3(1): p. e2011053-e2011053.

13. KARIM F., SHAIKH U., ADIL S.N., and KHURSHID M., Clinical characteristics, outcome and early induction deaths in patients with acute promyelocytic leukaemia: a five-year experience at a tertiary care centre. Singapore Med J, 2014. 55(8): p. $443-447$.

14. SILVA W.F.D., JR., ROSA L.I.D., MARQUEZ G.L., BASSOLLI L., TUCUNDUVA L., SILVEIRA D.R.A., et al., Real-life Outcomes on Acute Promyelocytic Leukemia in Brazil - Early Deaths Are Still a Problem. Clin Lymphoma Myeloma Leuk, 2019. 19(2): p. e116-e122.

15. PAULSON K., SEREBRIN A., LAMBERT P., BERGERON J., EVERETT J., KEW A., et al., Acute promyelocytic leukaemia is characterized by stable incidence and improved survival that is restricted to patients managed in leukaemia referral centres: a pan-Canadian epidemiological study. Br J Haematol, 2014. 166(5): p. 660-666.

16. PARK J.H., QIAO B., PANAGEAS K.S., SCHYMURA M.J., JURCIC J.G., ROSENBLAT T.L., et al., Early death rate in acute promyelocytic leukemia remains high despite all-trans retinoic acid. Blood, 2011. 118(5): p. 1248-1254.

17. MCCLELLAN J.S., KOHRT H.E., COUTRE S., GOTLIB J.R., MAJETI R., ALIZADEH A.A., et al., Treatment advances have not improved the early death rate in acute promyelocytic leukemia. Haematologica, 2012. 97(1): p. 133. 
18. LO-COCO F., AVVISATI G., VIGNETTI M., BRECCIA M., GALLO E., RAMBALDI A., et al., Front-line treatment of acute promyelocytic leukemia with AIDA induction followed by risk-adapted consolidation for adults younger than 61 years: results of the AIDA-2000 trial of the GIMEMA Group. Blood, 2010. 116(17): p. 3171-9.

19. SANZ M.A., LO COCO F., MARTÍN G., AVVISATI G., RAYÓN C., BARBUI T., et al., Definition of relapse risk and role of nonanthracycline drugs for consolidation in patients with acute promyelocytic leukemia: a joint study of the PETHEMA and GIMEMA cooperative groups. Blood, 2000. 96(4): p. 1247-1253.

20. CHEN Y., KANTARJIAN H., WANG H., CORTES J., and RAVANDI F., Acute promyelocytic leukemia: a population-based study on incidence and survival in the United States, 1975-2008. Cancer, 2012. 118(23): p. 5811-8.

21. SANZ M.A., MONTESINOS P., VELLENGA E., RAYON C., DE LA SERNA J., PARODY R., et al., Risk-adapted treatment of acute promyelocytic leukemia with all-trans retinoic acid and anthracycline monochemotherapy: long-term outcome of the LPA 99 multicenter study by the PETHEMA Group. Blood, 2008. 112(8): p. 3130-4.

22. ADES L., SANZ M.A., CHEVRET S., MONTESINOS P., CHEVALLIER P., RAFFOUX E., et al., Treatment of newly diagnosed acute promyelocytic leukemia (APL): a comparison of French-Belgian-Swiss and PETHEMA results. Blood, 2008. 111(3): p. $1078-84$

23. KELAIDI C., CHEVRET S., DE BOTTON S., RAFFOUX E., GUERCI A., THOMAS X., et al., Improved outcome of acute promyelocytic leukemia with high WBC counts over the last 15 years: the European APL Group experience. J Clin Oncol, 2009. 27(16): p. 2668-76.

24. SOBAS M., CZYŻ A., MONTESINOS P., ARMATYS A., HELBIG G., HOŁOWIECKA A., et al., Outcome of a Real-Life Population of Patients With Acute Promyelocytic Leukemia Treated According to the PETHEMA Guidelines: The Polish Adult Leukemia Group (PALG) Experience. Clin Lymphoma Myeloma Leuk, 2019.

25. JÁCOMO R.H., MELO R.A.M., SOUTO F.R., DE MATTOS É.R., DE OLIVEIRA C.T., FAGUNDES E.M., et al., Clinical features and outcomes of 134 Brazilians with acute promyelocytic leukemia who received ATRA and anthracyclines. Haematologica, 2007. 92(10): p. 1431.

26. SANZ M.A., MONTESINOS P., RAYON C., HOLOWIECKA A., DE LA SERNA J., MILONE G., et al., Risk-adapted treatment of acute promyelocytic leukemia based on all-trans retinoic acid and anthracycline with addition of cytarabine in consolidation therapy for high-risk patients: further improvements in treatment outcome. Blood, 2010. 115(25): p. 5137-46.

27. DE LA SERNA J., MONTESINOS P., VELLENGA E., RAYON C., PARODY R., LEON A., et al., Causes and prognostic factors of remission induction failure in patients with acute promyelocytic leukemia treated with all-trans retinoic acid and idarubicin. Blood, 2008. 111(7): p. 3395-402.

28. SANZ M.A. and MONTESINOS P., Open issues on bleeding and thrombosis in acute promyelocytic leukemia. Thromb Res, 2010. 125: p. S51-S54.

29. LEHMANN S., RAVN A., CARLSSON L., ANTUNOVIC P., DENEBERG S., MOLLGARD L., et al., Continuing high early death rate in acute promyelocytic leukemia: a population-based report from the Swedish Adult Acute Leukemia Registry. Leukemia, 2011. 25(7): p. 1128-34.

30. PARK J.H., QIAO B., PANAGEAS K.S., SCHYMURA M.J., JURCIC J.G., ROSENBLAT T.L., et al., Early death rate in acute promyelocytic leukemia remains high despite all-trans retinoic acid. Blood, 2011. 118(5): p. 1248-54.

31. BURNETT A.K., HILLS R.K., GRIMWADE D., JOVANOVIC J.V., CRAIG J., MCMULLIN M.F., et al., Inclusion of chemotherapy in addition to anthracycline in the treatment of acute promyelocytic leukaemia does not improve outcomes: results of the MRC AML15 trial. Leukemia, 2013. 27(4): p. 843-851.

32. LENGFELDER E., GORLICH D., NOWAK D., SPIEKERMANN K., HAFERLACH C., KRUG U., et al., Frontline therapy of acute promyelocytic leukemia: Randomized comparison of ATRA and intensified chemotherapy versus ATRA and anthracyclines. Eur J Haematol, 2018. 100(2): p. 154-162.

33. TALLMAN M.S., ANDERSEN J.W., SCHIFFER C.A., APPELBAUM F.R., FEUSNER J.H., WOODS W.G., et al., All-trans retinoic acid in acute promyelocytic leukemia: long-term outcome and prognostic factor analysis from the North American Intergroup protocol. Blood, 2002. 100(13): p. 4298-302.

34. NØRGAARD J.M., FRIIS L.S., KRISTENSEN J.S., SEVERINSEN M.T., MØLLE I., MARCHER C.W., et al., Addressing the room for improvement in management of acute promyelocytic leukemia. European Journal of Haematology, 2019. 102(6): p. 479-485.

35. REGO E.M., KIM H.T., RUIZ-ARGUELLES G.J., UNDURRAGA M.S., URIARTE MDEL R., JACOMO R.H., et al., Improving acute promyelocytic leukemia (APL) outcome in developing countries through networking, results of the International Consortium on APL. Blood, 2013. 121(11): p. 1935-43.

Received $10^{\text {th }}$ February 2020 